\title{
Research on the Dynamic Model of Mandatory Disclosure Quality and Investment Efficiency
}

\author{
Zhibiao Zhu $^{1, *}$, John Hoffmire ${ }^{2}$ and Fusheng Wang ${ }^{1}$ \\ ${ }^{1}$ School of Management, Harbin Institute of Technology, Harbin, Heilongjiang, 150001, P.R. China; ${ }^{2}$ Said Business \\ School, University of Oxford, Oxford, OX1 5NY, United Kingdom
}

\begin{abstract}
This paper investigates the dynamic relationship between mandatory disclosure quality and investment efficiency. Through building a three dates' model in which the firm's investment decision is jointly affected by the short-term share price in the capital market and by the total cash flows of the firm, the paper analyzes the impact of strategy of information disclosure of investment efficiency. The results show that when the firm's mandatory disclosure quality is very low, it cannot affect the firm's investment decision; when the firm's mandatory disclosure quality is enhanced, it can reduce overinvestment or underinvestment and leads to enhancing investment efficiency. Further, this paper uses 3,726 samples of Chinese listed firms during the period 2008-2013 to test the empirical model and finds that the mandatory disclosure quality is negatively associated with underinvestment and overinvestment. This paper contributes to expand the information disclosure literature by examining the consequences of information disclosure.
\end{abstract}

Keywords: Cash flows, investment efficiency, mandatory disclosure quality, share price.

\section{INTRODUCTION}

In this paper, the dynamic relationship between mandatory disclosure quality and investment efficiency [1] is investigated. The investment decision has become a hot issue in the field of modern corporate finance. Whether the firm can make an investment decision correctly or not depends on its objectives [2] and the information about the cash flow of the investment project. There exist two important objectives for the firm which discloses information to maximize the shortterm share price and the long-term total cash flow payoffs [3]. On one hand, the firm conveys relevant information to outside investors affecting the share price [4]. The accurate price of the share provides a better investment incentive to the management and the firm to make the right investment decision to enhance investment efficiency [5]. On the other hand, the firm and the management could control the strategy of information disclosure to affect the share price [6]. If the firm's mandatory information quality is low, the company may experience a decrease in share price, which may also correspond to the firm's underinvestment or overinvestment [7]. Some researchers [8] have examined how investment decisions are affected by the reliable and relevant components of accounting reports. However, the related papers above have not discussed the dynamic relationship between mandatory disclosure quality and investment efficiency based on the perspective of cash flows generated by an investment project.

This paper uses a three dates' model in which the firm's investment decision is jointly affected by the short-term

\footnotetext{
*Address correspondence to this author at the School of Management, Harbin Institution of Technology, Harbin, Heilong, 150001, P.R. China; Tel: +86 451 86414023; Fax: +86 45286414025 ; E-mail: zhibiao.zhu@hotmail.com
}

share price in the capital market and by the total cash flows of the firm. Considering the information about the profitability of the investment project, the firm makes the investment decision which generates cash flows in the short-term and long-term. The firm's objective is to maximize the shortterm share price and the long-term total cash flows. The share price reflects the rational expectation of firm value based on a public report of the short-term cash flows. The market's inability to identify the sources of the first-period cash flow may induce the firm to make an inefficient investment which is not best for the shareholders. In turn, the suboptimal investment decision (overinvestment or underinvestment) also can affect the share price and total cash flows. This paper shows that when the firm's mandatory disclosure quality is very low, it cannot affect the firm's investment decision; when the firm's mandatory disclosure quality is enhanced, it can reduce overinvestment or underinvestment and leads to enhancing the investment efficiency. Further, this paper uses 3,726 samples of Chinese listed firms during the period 2008-2013 to test the empirical model and finds that the mandatory disclosure quality is negatively associated with underinvestment and overinvestment.

This paper contributes to three aspects. First, this paper can expand the information disclosure literature by examining the consequences of information quality [9]. Second, this paper indicates that how mandatory information affects investment efficiency in dynamic information environments. Last, this paper may provide policy-makers with useful knowledge for designing mandatory information disclosure regulations in the light of their overall impact on the firm's investment efficiency.

The remaining paper proceeds as follows. Section 2 describes the model in detail. Section 3 analyzes the dynamic equilibrium of mandatory disclosure quality and investment 
efficiency. Section 4 tests mandatory disclosure quality and investment efficiency. Section 5 concludes the paper.

\section{THE MODEL}

In an efficient and competitive capital market, both firms and investors are risk-neutral. There are three dates in this model, $T_{0}$ means present, $T_{1}$ means the short-term and $T_{2}$ means the long-term. The firm focuses on both the shortterm effects such as the share price and long-term effects such as the total cash flows [10]. The firm makes the investment decision independently and cannot communicate with outside investors before making investment decisions. This paper, [11] defines $x_{1}$ as the cash flow which is generated by the firm's ongoing activities on the date $T_{1}$ and $x_{2}$ is the cash flow generated by the firm's ongoing activities on the date $T_{2}$.It is assumed that cash flow $x_{1}$ and cash flow $x_{2}$ follow the joint distribution given by:

$$
\left[\begin{array}{l}
x_{1} \\
x_{2}
\end{array}\right] \sim N\left(\left[\begin{array}{l}
\mu \\
\mu
\end{array}\right],\left[\begin{array}{cc}
\sigma^{2} & \alpha \sigma^{2} \\
\alpha \sigma^{2} & \sigma^{2}
\end{array}\right]\right)
$$

On the date $T_{0}$, the firm finds an opportunity for an investment project. For instance, the firm may create a new technology which could improve its products or may find a new market demand which could expand its revenue. Defining $r$ as the project's profitability, where $r$ is normally distributed with mean $r_{0}$ and variance $\sigma_{r}^{2}$, where $r \sim N\left(r_{0}, \sigma_{r}^{2}\right)$. On the date $T_{1}$, the firm makes the decision to choose an investment level $I$, where $I \in R^{+}$. When the firm decides to invest in the project, $I>0$. When the firm decides not to invest in the project, $I=0$. The investment project generates cash flows on the date $T_{1}$ denoted by $f_{1}(r, I)$ and the investment project also generates cash flows on the date $T_{2}$ denoted by $f_{2}(r, I)$. For tractability, this paper assumes cash flows $f_{1}(r, I)=\pi \sqrt{r I}$ and cash flows $f_{2}(r, I)=(2-\pi) \sqrt{r I}$, where $\pi \in[0,2]$. Therefore, the total cash flows of the investment project $(2 \sqrt{r I})$ depend on the profitability variable $r$ and the firm's investment level $I$. The timing of the total cash flows depends on $\pi$. When $\pi$ is higher, more cash flow is generated during the shortterm.

Thus, when the firm chooses to invest in the project, the total cash flows $C_{1}$ contain cash flows $x_{1}$ generated by the ongoing activities and cash flows $f_{1}(r, I)$ generated by the investment project on the date $T_{1}$. The total cash flows $C_{2}$ contain cash flows $x_{2}$ generated by the ongoing activities and cash flows $f_{2}(r, I)$ generated by the investment project on the date $T_{2}$.

$$
\begin{aligned}
& C_{1}=x_{1}+f_{1}(r, I)=x_{1}+\pi \sqrt{r I} \\
& C_{2}=x_{2}+(2-\pi) f_{2}(r, I)=x_{2}+(2-\pi) \sqrt{r I}
\end{aligned}
$$

On the date $T_{1}$, the share price $P$ is equal to the expected total cash flows on the date $T_{2}$. This paper defines all the available information on the date $T_{1}$ by $\omega$. Let $P=E\left(C_{1}+C_{2} \mid \omega\right)$. The information $\omega$ contains public information and the information $q$ about cash flows $f_{1}(r, I)$ generated by the investment project on the date $T_{1}$. Denoting $q=\pi \sqrt{r I}+\varepsilon_{q}$, where $\varepsilon_{q}$ is normally distributed with mean 0 and variance $\sigma_{q}^{2}, q \sim N\left(0, \sigma_{q}^{2}\right)$. The variance represents the quality of information q about cash flow $f_{1}(r, I)$. If $\sigma_{q}^{2}$ is high, $q$ conveys coarse information about the project's cash flow $f_{1}(r, I)$. If $\sigma_{q}^{2}$ is low, $q$ conveys precise information about the project's cash flow $f_{1}(r, I)$.

The firm's objectives have both long-term and short-term components [12]. In other words, the firm wants to maximize the total cash flow $\mathrm{C}$ and the share price $P$. Because of business cycle, liquidity risk and CEO compensation [13], a portion of the firm shares $\beta$ must be sold to the new shareholders at the market price $P$ at the end of the period 3. The older shareholders will hold the remaining $(1-\beta)$ portion of the firm's shares. Based on the method [14], this paper builds the firm's objective function as follows:

\section{MANDATORY DISCLOSURE QUALITY AND IN- VESTMENT EFFICIENCY ANALYSIS}

To analyze the dynamic relationship, this paper builds an approximation assumption [15]. Let random variables $x, y$ and $z$ be jointly normally distributed. Based on the conditional density function $f(x+z \mid y+a z)$ and the conditional cumulative density function $G(z \mid y+a z)$, the following equations for all realizations of $y+a z$ are assumed :

$$
\begin{aligned}
& \int_{z>0} \int_{x}(x+z) f(x, z \mid y+a z) d x d z+G(0 \mid y+a z) \int_{x} x f(x \mid y) d x \\
& \cong \int_{z} \int_{x}(x, z \mid y+a z) d x d z
\end{aligned}
$$

Thus, based on all the available information $\omega$ and the approximation assumption, there exists a unique linear equilibrium.

I. An equilibrium linear pricing function:

$P\left(C_{1}, \mathrm{q}\right)=\mathrm{a}_{q}+\mathrm{b}_{c_{1}} C_{1}+b_{q} q$

Where,

$$
\begin{aligned}
& a_{q}=\left(2-b_{c_{1}}\right) \mu+\left(2-\pi b_{c_{1}}-\pi b_{q}\right) \sqrt{\delta_{q}} r_{0} \\
& \mathrm{~b}_{c_{1}}=\frac{(1+\alpha) \pi^{2} \delta_{q} \sigma^{2} \sigma_{r}^{2}+(1+\alpha) \sigma^{2} \sigma_{q}^{2}+2 \pi \delta_{q} \sigma_{q}^{2} \sigma_{r}^{2}}{\pi^{2} \delta_{q} \sigma^{2} \sigma_{r}^{2}+\sigma^{2} \sigma_{q}^{2}+\pi^{2} \delta_{q} \sigma_{q}^{2} \sigma_{r}^{2}}
\end{aligned}
$$


$\mathrm{b}_{q}=\frac{[2-(1+\alpha) \pi] \pi \delta_{q} \sigma^{2} \sigma_{r}^{2}}{\pi^{2} \delta_{q} \sigma^{2} \sigma_{r}^{2}+\sigma^{2} \sigma_{q}^{2}+\pi^{2} \delta_{q} \sigma_{q}^{2} \sigma_{r}^{2}}$

II. An equilibrium investment function:

$I^{q}(r)=\left\{\begin{array}{cc}\delta_{q} r, & r \geq 0 \\ 0 & r<0\end{array}\right.$

Where,

$\delta_{q}=\left(1-\beta+\frac{\beta \pi\left(b_{C_{1}}+b_{q}\right)}{2}\right)^{2}$

Through the analysis of equilibrium, substituting $b_{C_{1}}$ and $\mathrm{b}_{q}$ into $\delta_{q}(3-4)$, the following formula is used:

$\left(\sqrt{\delta_{q}}-1\right)\left(\pi^{2} \delta \frac{\sigma_{r}^{2}}{\sigma_{q}^{2}}+1+\pi^{2} \delta_{q} \frac{\sigma_{r}^{2}}{\sigma^{2}}\right)=\beta\left[\frac{\pi(1+\alpha)}{2}-1\right]$

The second bracket in the left of equation is always equal to a number greater than zero and when $\sigma_{q}^{2}$ increases, its whole value decreases. Therefore, the value of the first bracket in the left of equation is constant with the right of equation. The following results are achieved:

First, when $\pi=\pi^{*}=2 /(1+\alpha)$, the value of $\delta_{q}=1$. At this point, the firm's investment level is optimal and mandatory disclosure quality has no influence on the firm's investment decision. Also, when $\sigma_{\mathrm{q}}^{2} \rightarrow+\infty$, the value of $b_{q}=0$. This means that the quality of mandatory disclosure is very low. In other words, mandatory disclosure quality does not influence the firm's investment decision.

Second, when $\pi>\pi^{*}=2 /(1+\alpha)$, the value of $\delta_{q}>1$. This indicates that the firm has incentives to overinvest. With the improvement of mandatory disclosure quality ( $\sigma_{q}^{2}$ goes up), the value of $\delta_{q}$ goes down, which means that the firm reduces excessive investment which leads to enhancing investment efficiency.

Last, when $\pi<\pi^{*}=2 /(1+\alpha)$, the value of $\delta_{q}<1$. This indicates that the firm has incentives to underinvest. With the improvement of mandatory disclosure quality, $\sigma_{q}^{2}$ goes down and the value of $\delta_{q}$ goes up, which means that the firm reduces underinvestment and enhances investment efficiency.

\section{EMPIRICAL TEST}

\subsection{Research Hypotheses}

Recently, a large amount of literature has been published on the effects of information disclosure quality on invest- ment efficiency [15-17].The mandatory disclosure quality can be associated with investment efficiency through at least two channels. First, mandatory disclosure conveys firm's specific information to investors and reduces information asymmetry between the firm and investors and among investors. Thus, it could mitigate adverse selection costs and reduce the costs of raising capital [18]. For example, firms disclose more information to increase liquidity by reducing information asymmetry between the firms and investors. On the other hand, the existence of information asymmetry between firms and investors could lead the suppliers of capital to discount stock prices and to increase the cost of raising capital because investors would infer that firms' raising funds are inappropriate [19]. Therefore, mandatory disclosure quality mitigates information asymmetry and increases investment efficiency by reducing the costs of external financing for firms [20]. Secondly, it is commonly argued that mandatory disclosure quality plays an important role in mitigating agency problems between the managers and investors. For example, a compensation contract is always based on mandatory information [21] and is an important source of information used by investors to monitor managers [22]. In addition, mandatory information contributes to the monitoring role of stock markets as an important source of firmspecific information [23]. Therefore, if mandatory disclosure quality reduces agency problems between the managers and investors, it can then improve the investment efficiency by increasing shareholders' ability to monitor managers and thus reduce financing costs and improve project selection.

Based on the above discussion about how mandatory disclosure quality affects both adverse selection and agency conflicts, the approach [24] to test whether mandatory disclosure from emerging markets helps mitigate both underinvestment and overinvestment is followed. In other words, this paper investigates the financial capital investment inefficiencies under less conductive conditions than those examined in the prior research. The above discussion leads to the hypotheses as follows:

H1: Mandatory disclosure quality is negatively associated with underinvestment.

$\mathrm{H} 2$ : Mandatory disclosure quality is negatively associated with overinvestment.

\subsection{Research Design}

\subsubsection{Data Source}

The financial data needed to test this paper was obtained from the Shenzhen Stock Exchange (SZSE), and the China Stock Market and Accounting Research (CSMAR) database. Information was collected manually through the annual financial reports of individual firms. The sample selection process is as follows. Firstly, the research purposes were considered and financial firms were excluded because their general characteristics are much different from the common listed firms. Secondly, those firms were excluded which are currently restructuring their assets and raising equity. Thirdly, the paper also excluded the firms for which data is incomplete. Lastly, based on the A-M industry classification standard in China, each industry requires at least 20 observa- 
tions each year. Therefore, the paper used 3,726 samples during the period from 2008 to 2013.

\subsubsection{Proxy for Investment Efficiency}

Investment efficiency refers to the firms that undertake all projects with positive net present value. To construct the measurement of investment efficiency, consistent with prior research (Richardson, 2006; Biddle et al., 2009; Chen et al., 2011), a model is built which predicts the firm's investment efficiency and subsequently, residuals from this model are a proxy for inefficient investment. Consequently, this model is used to measure the investment efficiency and deviations from expected investment methods, which is a function of growth opportunities. The paper describes the negative deviations from expected investment as underinvestment, and the positive deviations from expected investment as overinvestment. Both underinvestment and overinvestment are inefficient investments. The model is described below:

$$
\begin{aligned}
\text { Investment }_{i, t} & =\alpha_{0}+\alpha_{1} \text { Growth }_{i, t-1}+\alpha_{2} \text { Leverage }_{i, t-1} \\
& +\alpha_{3} \text { Cash }_{i, t-1}+\alpha_{4} \text { Size }_{i, t-1}+\alpha_{5} \text { Return }_{i, t-1} \\
& +\alpha_{6} \text { Age }_{i, t-1}+\alpha_{7} \text { Investment }_{i, t-1}+\varepsilon_{i, t}
\end{aligned}
$$

Where Investment $i_{i, t}$ is the sum of capital expenditures, $R \& D$ expenditures, and acquisitions minus sales of property, plant, and equipment, scaled by lagged total assets for firm $i$ at the end of the year $t-1$. Growth $h_{i, t-1}$ is the annual revenue growth rate for firm $i$ at the end of the year $t-1$. Leverage $e_{i . t-l}$ is financial leverage, showing the ratio of long-term debt to the sum of long-term debt plus the market value of equity of firm $i$ at the end of the year $t-1$. Cash ${ }_{i . t-1}$ is the ratio of cash to the total assets of the firm $i$ at the end of the year $t-1$. Size $i, t-1$ is the $\log$ of total assets of the firm $i$ at the end of the year $t-1$. Return ${ }_{i, t}$ ${ }_{l}$ is the stock return of the firm $i$ at the end of the year $t-1$. $A g e_{i, t-1}$ is the difference between the first year when firm $i$ appears on the SZSE(Shenzhen Stock Exchange) at the end of the year $t-1$. Investment $t_{i-t-1}$ is the lag of investment.

\subsubsection{Proxy for Mandatory Disclosure Quality}

The objective of financial reporting is to provide the estimation of expected cash flow and useful information to help investors make reasonable decisions. Along with mandatory information disclosure, accruals quality is one of the most important and comprehensive issues for concerned investors. Accruals quality is not only an important tool for investors to make investment decisions but also an important foundation for firms' contract designs. The article provides a proxy for mandatory disclosure quality using measures of accruals quality derived in the prior work based on the idea that accruals are estimates of future cash flow. Specifically, the following model was analyzed for each industry that had at least 20 observations:

$$
T C A_{i, t}=\beta_{0}+\beta_{1} C F O_{i, t-1}+\beta_{2} C F O_{i, t}+\beta_{3} C F O_{i, t+1}+\beta_{4} \operatorname{Re} v_{i, t}+\beta_{5} P P E_{i, t}+\varepsilon_{i, t}
$$

Where $T C A_{i, t}$ is the total current accruals of firm $i$ at the end of the year $t ; C F O$ is the cash flow from operations ; $\operatorname{Rev}_{i, t}$ is the annual change in revenues of firm $i$ at the end of the year $t ; P P E_{i, t}$ is the property, plant, and equipment of firm $i$ at the end of the year $t$. The residuals from this equation represent the estimation errors in the current accruals that are not associated with operating cash flow and that cannot be explained by the change in revenue and the level of PPE. Given the short longitudinal time frame in this study, this paper follows Francis et al. (2005) and Srinidhi and Gul (2007) and uses the absolute value of this residual as a proxy for mandatory disclosure quality. In this paper, the absolute values of the Dechow-Dichev measure are multiplied by -1 (DD). Thus, higher values of DD represent higher mandatory disclosure quality.

\subsubsection{Empirical Model}

As the paper focuses on how mandatory information disclosure quality affects the investment efficiency, the hypotheses are tested by regressing the estimation of investment efficiency of the year $t$ with the estimation of mandatory information disclosure quality (MDQ) in the year $t-1$. The paper also estimates equation (3) separately for underinvestment and overinvestment. The empirical models are as follows:

$$
\begin{aligned}
\text { OverI }_{i, t} \text { orUnderI }_{i, t} & =\gamma_{0}+\gamma_{2} M D Q_{i, t-1}++\gamma_{3} \text { Size }_{i, t-1}+\gamma_{4} \text { Growth }_{i, t-1} \\
& +\gamma_{5} \text { Lev }_{i, t-1}+\gamma_{6} \text { Pay }_{i, t-1}+\gamma_{7} \text { Mfe }_{i, t-1}+\gamma_{8} \text { Vfo }_{i, t-1} \\
& +\gamma_{9} \text { State }_{i, t-1}+\sum \text { Industry }+\sum \text { Year }+\varepsilon_{i, t}
\end{aligned}
$$

Where:

OverI $I_{i, t}=$ positive excess investment, which is the residual of the investment model.

UnderI $I_{i, t}=$ negative excess investment, which equals the absolute value of the residual of the investment model.

$M D Q_{i,-1}=$ financial reporting quality which is the absolute residual of the modified model, multiplied by -1 .

Motivated by prior research, the paper also includes the $\log$ of firm size $\left(\right.$ Size $\left._{i, t-1}\right)$, annual revenue growth rate $\left(\right.$ Growth $\left._{i,-1}\right)$, financial leverage $\left(\operatorname{Lev}_{i, t-1}\right)$, the log of executive compensation $\left(\right.$ Pay $\left._{i, t-1}\right)$, the ratio of administrative expenses which is scaled by total assets $\left(M f e_{i, t-1}\right)$, operations cash flow scaled by total assets $\left(V f_{i, t-1}\right)$, and the nature of equity $\left(\right.$ State $\left._{i, t-1}\right)$ as control variables, as well as industry fixed effects.

\subsection{Empirical Results}

Table 1 provides descriptive statistics and correlations for the estimations of investment efficiency, mandatory information quality, and our main control variables. It shows that the sample consists of 3,726 firms' observations. In this sample, there are 2,056 $(1,670)$ firms associated with underinvestment (overinvestment) group. The mean (median) value for underinvestment is $0.069(0.048)$ and for overinvestment is $0.082(0.056)$. These indicate that there are more underinvestment firms than there are overinvestment samples. Also, there are more overinvestment firms with inefficiency degrees more serious than those of underinvestment firms. The mean value for mandatory information disclosure quality is 0.615 . The median is 0.528 , which shows that the general private information quality is good for listed firms in China. Finally, the researchers include descriptive statistics on firms' size, sales growth and other control variables. 
Table 1. Results of describe of variables.

\begin{tabular}{|c|c|c|c|c|c|c|}
\hline Variable & OBS & Mean & Median & STD & Min & $\operatorname{Max}$ \\
\hline UnderI & 2,056 & 0.069 & 0.048 & 0.135 & 0.000 & 1.415 \\
\hline OverI & 1,670 & 0.082 & 0.056 & 0.127 & 0.000 & 1.012 \\
\hline$M D Q$ & 3,726 & 0.615 & 0.528 & 0.092 & 0.041 & 0.969 \\
\hline Size & 3,726 & 23.51 & 20.63 & 1.216 & 11.35 & 36.27 \\
\hline Growth & 3,726 & 0.162 & 0.145 & 0.503 & -0.392 & 0.843 \\
\hline Lev & 3,726 & 0.620 & 0.599 & 0.828 & 0.000 & 1.360 \\
\hline Pay & 3,726 & 14.02 & 12.23 & 1.865 & 9.521 & 17.47 \\
\hline Mfe & 3,726 & 0.074 & 0.051 & 0.193 & 0.000 & 4.326 \\
\hline$V f_{0}$ & 3,726 & 0.072 & 0.058 & 0.084 & 0.009 & 0.518 \\
\hline State & 3,726 & 0.620 & 0.500 & 0.967 & 0.000 & 1.000 \\
\hline
\end{tabular}

Table 2. Mandatory disclosure quality and investment efficiency.

\begin{tabular}{|c|c|c|}
\hline Constant & $\begin{array}{c}0.183^{* * *} \\
(3.785)\end{array}$ & $\begin{array}{c}0.232 * * * \\
(4.359)\end{array}$ \\
\hline$M D Q_{i, t-1}$ & $\begin{array}{c}-0.051 * * * \\
(-3.942)\end{array}$ & $\begin{array}{c}-0.072 * * \\
(-4.576)\end{array}$ \\
\hline Year & Yes & Yes \\
\hline Adjust $R^{2}$ & 0.135 & 0.152 \\
\hline F Value & $26.984 * * *$ & $27.630 * * *$ \\
\hline$N$ & 2,056 & 1,670 \\
\hline
\end{tabular}

$*, * *, * * *$ Denote significance at the 10 percent, 5 percent, and 1 percent levels, respectively.

Table 2 reports the multiple regressions testing hypotheses $\mathrm{H} 1$ and $\mathrm{H} 2$. The estimated model is a regression of underinvestment (overinvestment) on mandatory disclosure quality, firm characteristics, industry and year fixed effects. Because the samples contain unbalanced panel data including time-series and cross-section data, the paper used data from 2008-2013 to measure underinvestment efficiency and overinvestment efficiency in response to the measurement mandatory disclosure quality from 2007 to 2012. As can be seen from the table, the regression coefficients of mandatory disclosure quality are negative, and are significantly under $1 \%$ significance level. The estimated coefficients suggest that moving from bottom to top, the decline in mandatory disclosure quality is associated with a reduction in underinvestment(overinvestment) of $5.1 \%(7.2 \%)$. Given that the mean of underinvestment is $6.9 \%(8.2 \%)$, the effect is economically significant. It indicates that the mandatory disclosure quality is negatively associated with underinvestment and overinvestment, which means that high mandatory disclosure quality can reduce moral hazard and adverse selec- tion between the managers and investors. As a result, high mandatory disclosure quality can reduce underinvestment and overinvestment leading to increased investment efficiency which strongly supports hypotheses $\mathrm{H} 1$ and $\mathrm{H} 2$.

\section{CONCLUSION}

This paper analyzes the dynamic relationship between mandatory disclosure quality and investment efficiency. The paper analyzes the impact of strategy of information disclosure related to investment efficiency by building a three dates model in which the firm's investment decision is jointly affected by the short-term share price in the capital market and by the total cash flows of the investment project. This paper shows that when the firm's mandatory disclosure quality is very low, it cannot affect the firm's investment decision; when the firm's mandatory disclosure quality is enhanced, it can reduce overinvestment or underinvestment and lead to enhancing investment efficiency. Further, this paper finds that mandatory disclosure quality is negatively associated with underinvestment and overinvestment. This paper 
contributes to expand the information disclosure literature by examining the consequences of information quality. It also indicates how mandatory information influences investment efficiency in dynamic information environments, and provides policy-makers with useful knowledge for designing mandatory information disclosure regulations in the light of their overall impact on the firm's investment efficiency.

\section{CONFLICT OF INTEREST}

The authors confirm that this article content has no conflict of interest.

\section{ACKNOWLEDGEMENTS}

This study was funded by grants from the National Natural Science Foundation of China (Nos.71031003) and Social Science Foundation of Heilongjiang Province (Nos.14C011). We are grateful to the University of Oxford for providing a good environment to conduct much of this research.

\section{REFERENCES}

[1] F. Modigliani, and M. Miller, "The cost of capital, corporation finance, and the theory of investment", American Economic Review, vol. 48, no. 3, pp. 261-297, 1958.

[2] M. C. Jensen, and W. H. Meckling, "Theory of the firm: managerial behavior, agency costs and ownership structure", Journal of Financial Economics, vol. 3, no. 4, pp. 305-360, 1976.

[3] M. C. Jensen, "Agency cost of free cash flow, corporate finance, and takeovers", American Econonic Review, vol. 76, no. 2, pp. 323329, 1986.

[4] J. Stein, "Agency, information and corporate investment", In: George Constantinides, Milt Harris, René Stulz (Eds.): Handbook of the Economics of Finance. New York: Elsevier, pp. 111-165, 2003.

[5] S. Richardson, "Over-investment of free cash flow", Review of Accounting Studies, vol. 11, no. 1, pp. 159-189, 2006.

[6] J. Stein, "Efficient capital markets, inefficient firms: A model of myopic corporate behavior", The Quarterly Journal of Economics, vol. 104, no. 4, pp. 655-669, 1989.

[7] P. J. Liang and X. Wen, "Accounting measurement basis, market mispricing, and firm investment efficiency", Journal of Accounting Research, vol. 45, no. 1, pp. 155-197, 2007.

[8] S. Chen, D. Matsumoto, and S. Rajgopal, "Is silence golden? An empirical analysis of firms that stop giving quarterly earnings guid- ance", Journal of Accounting and Economics, vol. 31, no. 3, pp. 134-150, 2001.

[9] C. S. Lennox, and W. C. Park, "The informative of earnings and management's issuance of earnings forecasts", Journal of Accounting and Economics, vol. 42, no. 3, pp. 439-458, 2006.

[10] H. Itoga, G.T. R. Lin, F. C. H. Yang, and J. Z. Shyu, "Dynamics of industrial cluster scenarios", Revista de Cercetare si Interventie Sociala, vol. 47, pp. 233-249, 2014.

[11] N. Langberg, and K. Sivaramakrishnan, "Voluntary disclosures and analyst feedback", Journal of Accounting Research, vol. 48, no. 3, pp. 603-646, 2010.

[12] J. R. Graham, R. C. Harvey and S. Rajgopal, "The economic implications of corporate financial reporting" Journal of Accounting and Economics, vol. 40, no. 1, pp. 3-73, 2005.

[13] P. Gao, "Disclosure quality, cost of capital, and investor welfare", The Accounting Review, vol. 85, no. 1, pp. 1-29, 2010.

[14] R . A. Dye, "Investor sophistication and voluntary disclosures", Review of Accounting Studies, vol. 3, no. 3, pp. 261-287, 1998.

[15] S. Dutta, and B. Trueman, "The interpretation of information and corporate disclosure strategies", Review of Accounting Studies, vol. 7, no. 1, pp. 75-96, 2002.

[16] J. Suijs, "Voluntary disclosure of information when firms are uncertain of investor response", Journal of Accounting and Economics, vol. 43, no. no. 2, pp. 391-410, 2007.

[17] R. A. Dye, and S. Sridhar, "Reliability-relevance trade-offs and the efficiency of aggregation", Journal of Accounting Research, vol. 42 , no. 1 , pp. $51-87,2004$

[18] R. Bushman, and A. Smith, "Financial accounting information and corporate governance", Journal of Accounting Economics, vol. 31, no. 6, pp. 237-333, 2001.

[19] P. Healy, and K. Palepu, "Information asymmetry, corporate disclosure and the capital markets: A review of the empirical disclosure literature", Journal of Accounting and Economics, vol. 31, no. 3, pp. 405-440, 2001.

[20] G. Biddle and G. Hilary, "Accounting quality and firm-level capital investment", The Accounting Review, vol. 81, no. 5, pp. 963-982, 2006.

[21] F. Chen, O. Hope, and Q. Li, "Financial reporting quality and investment efficiency of private firms in emerging markets", The Accounting Review, vol. 86, no. 4, pp. 1255-1288, 2011.

[22] S. Ramalingegowda, C. Wang and Y.Yu, "The role of financial reporting quality in mitigating the constraining effect of dividend policy on investment decisions", The Accounting Review, vol. 88, no. 3, pp. 1007-1039, 2013.

[23] V. Nagar, D. Nanda and P. Wysocki, "Discretionary disclosure and stock-based incentives," Journal of Accounting and Economics, vol. 34, pp. 283-309, 2003.

[24] X. Wen, "Voluntary disclosure and investment", Contemporary Accounting Research, vol. 30, no. 2, pp. 677-696, 2013.

\begin{tabular}{lrr}
\hline Received: June 10, 2015 & Revised: July 29, 2015 & Accepted: August 15, 2015 \\
(C) Zhu et al.; Licensee Bentham Open. &
\end{tabular}

This is an open access article licensed under the terms of the (https://creativecommons.org/licenses/by/4.0/legalcode), which permits unrestricted, noncommercial use, distribution and reproduction in any medium, provided the work is properly cited. 